\title{
Modelling hydraulic mixture movement along the extraction chamber bottom in case of hydraulic washout of the tuff-stone
}

\author{
Zinovii Malanchuk ${ }^{1 *}$, Viktor Moshynskyi ${ }^{2}$, Petro Martyniuk ${ }^{3}$, Sergii $_{\text {Stets }}{ }^{4}$, and Daniyar Galiyev ${ }^{5}$ \\ ${ }^{1}$ National University of Water Management and Nature Resources Use, Department of Development \\ of Deposits and Mining, 11 Soborna St., 33028 Rivne, Ukraine \\ ${ }^{2}$ National University of Water Management and Nature Resources Use, Department of Land, \\ Cadastre, Land Monitoring and Geoinformatics, 11 Soborna St., 33028 Rivne, Ukraine \\ ${ }^{3}$ National University of Water Management and Nature Resources Use, Department of Computer \\ Science and Applied Mathematics, 11 Soborna St., 33028 Rivne, Ukraine \\ ${ }^{4}$ National University of Water Management and Nature Resources Use, Institute of Postgraduate \\ Education, 1124 Serpnia St., 33000 Rivne, Ukraine \\ ${ }^{5}$ Institute of Mining named after D.A. Kunaev, Laboratory of Computer-Aided Design, 191 Abai Ave., \\ 050046 Almaty, Kazakhstan
}

\begin{abstract}
This paper presents the research results of the pulp movement process along the extraction chamber bottom to the suction pipe of the pulp lifting device in case of downhole hydraulic mining the volcanic tuff-stone. The washout process and hydraulically operated transportation of the tuffstone hydraulic mixture, when forming the extraction chamber, have been studied under various conditions and methods of exposure. As a result, the dominant parameters have been determined influencing the hydrodynamic washout technology as well as tuff-stone hydraulic mixture lifting to the alluviation map. The dependences have been substantiated of the washout process performance and transportation capacity of the hydraulic mixture flow on the determined parameters. To calculate the process of pulp flowover along the extraction chamber bottom to the intaking hydraulic elevator headwall, the systems of equations have been determined based on the modelling the movement of tuff-stone hydraulic mixture along the extraction chamber bottom during hydraulic washout. The dependences of the contact strength of the tuff-stone samples mined by downhole method on the time spent in water are presented, resulting in determination of the tuff-stone weakening coefficient and the degree of its saturation with water.
\end{abstract}

\section{Introduction}

An increased interest in the tuff-stone production is conditioned by the expansion of field of its application. An experience of its effective use in agriculture, the construction industry, and medicine $[1-5]$ requires improving its processing and bringing to the finished product in compliance with the terms of its use. Rich microelement composition of the tuff-stone,

\footnotetext{
*Corresponding author: malanchykzr@ukr.net
} 
availability of rare metal microelements, a high content of iron, titanium, native copper in the tuff-stone - motivate the necessity for their complex processing. Its initial stage is ore preparation of the rock mass before tuseful components recovery [6-9].

Most tuff-stone components are useful in industry, and, according to the requirements for the integrated use of raw materials, its processing technology should take into account in its schematic performance the possibility to separate into the required amount of monomineralic concentrates extracted from the tuff-stone rock mass [10 - 13]. Even with account of the main components (native copper, iron and titanium) that are of industrial interest, processing of the dump tuff-stone, given the prospects for the area of their occurrence, is economically feasible, environmentally sound and socially appropriate (Table 1).

Table 1. The elements content in the tuff-stone samples in various quarries (oncentration, \%).

\begin{tabular}{|l|c|c|c|}
\hline \multicolumn{1}{|c|}{ Element name } & Rafalivskyi quarry & $\begin{array}{c}\text { Berestovetskyi } \\
\text { quarry }\end{array}$ & $\begin{array}{c}\text { Ivanova Dolyna } \\
\text { quarry }\end{array}$ \\
\hline Aluminum & 0.03 & 10.2 & 3.0 \\
\hline Silicon & $30-32$ & 57.2 & 42.0 \\
\hline Phosphorus & 0.1 & 0 & 0.15 \\
\hline Sulphur & 1.2 & 0.3 & 0 \\
\hline Potassium & 1.3 & 2.4 & 4.8 \\
\hline Calcium & $6.4-12.1$ & 15 & 37.5 \\
\hline Titanium & $2.8-4.0$ & 1.3 & 0.5 \\
\hline Chromium & 0.2 & 0.05 & 0.1 \\
\hline Manganese & 0.070 & 0.12 & 0.07 \\
\hline Iron & $48-50$ & 12.8 & 7.0 \\
\hline Nickel & 0.2 & 0.1 & 0.01 \\
\hline Copper & $0.4-0.7$ & 0.17 & $0.6-1.0$ \\
\hline Zinc & 0.05 & 1.2 & 0.07 \\
\hline Strontium & $0.07-0.1$ & 0.07 & 0.07 \\
\hline
\end{tabular}

Since the elements content stability is an important issue in the deposit research, beginning with 2015 , the problems of the tuff-stone extraction and processing are studied in Rafalivskyi basalt quarry. The results of the spectral rapid testing are presented in Table 2, which indicate a relatively stable content of copper, iron, titanium in the tuffstone, excluding serious changes in their processing technology over a long period of time.

Table 2. Results of the tuff-stone spectral rapid testing.

\begin{tabular}{|l|c|c|c|c|c|}
\hline \multirow{2}{*}{ Element name } & \multicolumn{6}{|c|}{ Elements content in the samples of tuff-stone in Rafalivskyi } \\
\cline { 2 - 6 } & 2015 & 2016 & 2017 & 2018 & 2019 \\
\hline Aluminum & 0 & 0.07 & 0.07 & 0.03 & 0.07 \\
\hline Silicon & 30.916 & 32.1 & 31.6 & 32.0 & 32.5 \\
\hline Phosphorus & 0.1 & 0.15 & 0.15 & 0.15 & 0.07 \\
\hline Lead & 0.5 & 0.3 & 0.5 & 0.3 & 0.3 \\
\hline Potassium & 1.281 & 1.41 & 1.51 & 1.52 & 1.60 \\
\hline Calcium & 6.34 & 9.8 & 10.8 & 12.5 & 12.1 \\
\hline Titanium & 3.98 & 7.0 & 2.8 & 1.8 & 2.6 \\
\hline Chromium & 0.198 & 0.3 & 0.1 & 0.07 & 0.07 \\
\hline Manganese & 0.81 & 0.05 & 0.07 & 0.15 & 0.15 \\
\hline Iron & 52.06 & 48.1 & 51.3 & 50.8 & 49.9 \\
\hline Nickel & 0.217 & 0.07 & 0.05 & 0.09 & 0.05 \\
\hline Copper & 0.70 & 0.2 & 0.6 & 0.40 & 0.45 \\
\hline Zinc & 0.055 & 0.05 & 0.007 & 0.009 & 0.007 \\
\hline Strontium & 0.106 & 0.006 & 0.007 & 0.007 & 0.007 \\
\hline Zirconium & 0.28 & 0.2 & 0.15 & 0.1 & 0.15 \\
\hline Cobalt & 0.02 & 0.01 & 0.05 & 0.05 & 0.03 \\
\hline
\end{tabular}


It should be noted that already at the initial stages of research on the usefull rock composition when developing the methods for their ore preparation and benefication, certain peculiarities have been set $[14,15]$. Among them the inclusions of native copper, identified even visually and presented in the samples in the form of point or thin films [16, 17]. In the process of crushing, grinding and sieving, these films are destroyed into separate parts less than 50 microns, which makes it difficult to recover them by means of separators. Compounds of iron and other metals are large particles, recovered from the total mass by magnetic field $[18,19]$. However, there is a large number of intergrown pieces from the silicate tuff-stone constituent, represented mainly by silicon and calcium, which are recovered by repeated grinding or by thermal means into slag through melting [20 - 22].

There are two methods of the tuff-stone extraction: the method of downhole hydraulic mining (DHM) and in a quarry. By a quarry method, the obtained tuff-stone is the lumpiest mass, when during the subsequent blasting of the quarry ledge, the tuff-stone, as less hard, has less lumpiness than basalt and lava-breccia. However, for a decision-making on its further processing technology, it becomes necessary to study its granular composition in the dump and during crushing.

During downhole hydraulic mining of zeolite-smectite volcanic tuff-stones [23 - 25], pulp is formed using rotating hydraulic monitor. Hydraulic monitor outwashes the rock seam by rotating at a certain angular velocity around the vertical symmetry axis of the extraction chamber [26-28]. According to the technology, the extraction chamber dimensions and the characteristics of the pulp flow-over process in it are determined by the performance and frequency of the hydraulic monitor rotation [29-32]. At the same time stree strain state should be also taken into account [33-36]. At low frequencies of the hydraulic monitor rotation, the pulp formed in some point of the extraction chamber will have time to reach the suction box before the hydraulic monitor jet reaches this place again. Therefore, to analyse the pulp flow-over processes in the extraction chamber, it is necessary to preliminary determine the permissible rotation frequencies of the hydraulic monitor, depending on its performance and washout radius $[37,38]$.

Given the fact that volcanic tuff-stones in the Rivne-Volyn region occur in seams with thicknesses from several meters to 100 and more meters, during the washout process, depending on the site of mining operations, extraction chambers can be used with a bottom set as in the mineral deposit itself, and in the underlying rocks [39-41]. This also determines the necessity to take into account the roughness of the chamber bottom.

\section{Research methodology}

Paper studies the tuff-stones characteristics in PJSC Rafalivskyi quarry of the Rivne region, which are identified during the basalts extraction in quarries or during the development of downhole hydraulic mining technology. The tuff-stones of this region have a zeolite-smectite base. The tuff-stone layers with a thickness of up to $150 \mathrm{~m}$, occur under the basalt mass and have a high density. They are half-rocks in hardness. The tuff-stone layers occurring at the surface, have lower hardness. All tuff-stones are sensitive to moisture influence. The influence of moisture on the tuff-stone has not been quantified [4-9].

The objective of research is to determine the patterns of changes in the granular composition of the zeolite-smectite tuff-stone both of a quarry mining and downhole mining, when it is weakened by the hydraulic monitor jet in the washout chamber.

Let us examine the extraction chamber bottom, with the suction box of the pulp lifting device in the center, which has a conical surface (Fig. 1). The diameter and inclination angle of the extraction chamber bottom are determined by the technological parameters of the downhole hydraulic mining process, then it is changed during mining. 
In the process of research, an experimental method is used to study the full-scale specimens of the tuff-stone. Samples are taken from eleven wells. The initial weight of the samples $m$, the indenter impressing force $P_{0}$ on the press are fixed by a known methodology. The indenter tip, according to the methodology, has a cross-sectional area of $1.0 \mathrm{~mm}^{2}$, therefore, the sample resistance voltage value $\sigma$ is also recorded on the device. After the samples are immersed into an aqueous medium, the time of exposure is recorded and the sample weight, the indenter impressing force $P_{0}$, and voltage value $\sigma$ are determined on a staged basis.

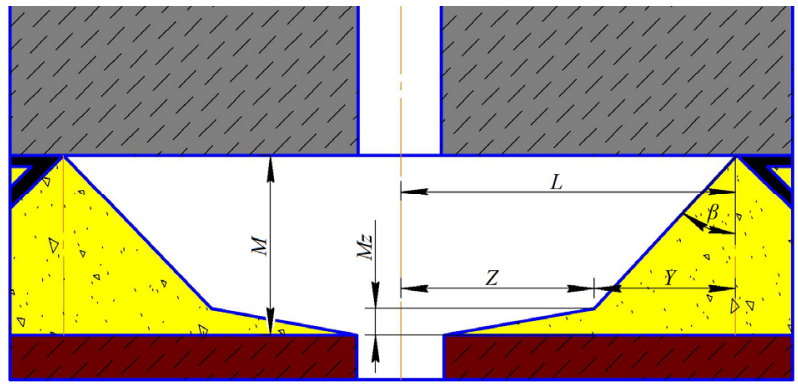

Fig. 1. Extraction chamber.

Based on the field studies result of the tuff-stone washout process [42], it is also known that the hydraulic mixture critical velocity is determined depending on the hydraulic size of the transported particles. Thus, at $u_{h}>u_{t v}$, an intermittent pulsed particles motion is observed, at $u_{h}>2 u_{t v}$, the solid's motion occurs in a suspended state, and at $u_{h}>(3-5) u_{t v}$, no depositing of solid is observed in the flow. For fragments of the broken rock, it is important to determine the conditions of pieces' friction against the solid boundaries of the flow, contact velocity, the relative velocities of the pieces moving in the fluid flow. By the value of the contact velocity, the conditions are judged of the hydromechanical action of the flow on the tuff-stone pieces at the moment of the translational motion start. The relative velocity of solid samples moving in the fluid flow is the most important kinematic characteristic of the hydraulic mixture movement, due to which the conditions are determined of the interaction between fluid and solids.

The hydrodynamic models of pulp flow-over over a conical surface were developed in publications, where the stationary parameters of the flow-over process have been determined and various factors influencing the nonuniform hydraulic mixture flow have been studied [43-45]. However, the dynamic characteristics of the process are studied insufficiently, as well as the roughness parameters of the flow solid boundary are not taken into account in these works.

\section{Results and discussion}

To analyze the process of pulp flow-over along the extraction chamber bottom, the model for moving a uniform fluid in a thin layer can be used, when to assume that the velocity across the layer thickness is the same and the presence of friction force between the fluid and the bottom is considered using empirical formulas. Such a model is relatively easy analysed and, with account of certain assumptions, leads to an analytical solution. Having assumed that the fluid flows over the surface in a thin layer, for the thickness of which, measured along the inward normal to the conical surface, the condition is satisfied: $h / x<<1$. Since the layer is thin, when considering the momenta equation, the acceleration 
of particles along the normal to the flow bottom and a change in the bulk force across the layer thickness will also be ignored.

Let us note, that the total length $l$ of the generatrix of the extraction chamber bottom and the distance $x_{k}$ along the generatrix to the suction box of the pulp lifting device are determined by washout radius of the hydraulic monitor (Fig. 2):

$$
\begin{gathered}
l=\frac{R}{\sin \beta} ; \\
x_{k}=\frac{R-R_{0}}{\sin \beta},
\end{gathered}
$$

where $R$ is washout radius of the hydraulic monitor; $R_{0}$ is suction box radius.

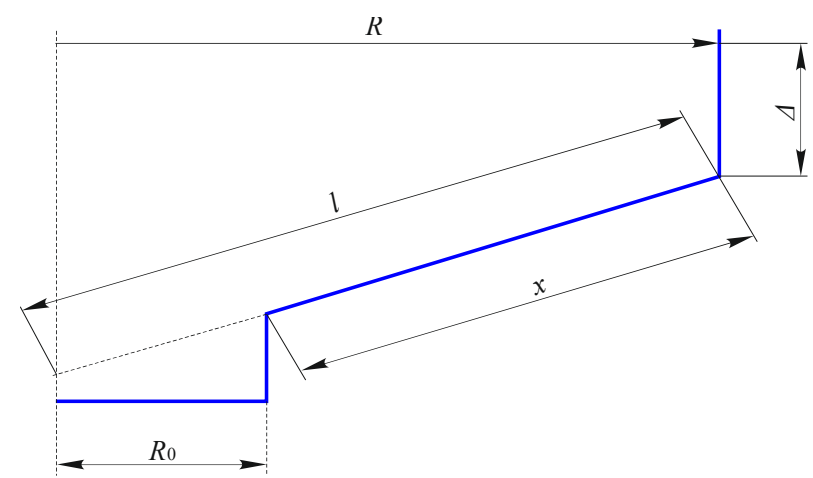

Fig. 2. For determining the distance along the generatrix of the extraction chamber.

To determine the main dependences and construct a mathematical model of the rock washout processes, the rotation veloicity of the hydraulic monitor is selected such that the pulp moves along the extraction chamber bottom without breaking the continuity of the flow on the conical surface of the extraction chamber bottom [46-48].

For the stationary flow-over of the broken tuff-stone along the extraction chamber bottom, the following theoretical model is the most sufficient, which is developed for the stationary flow [49]. If the flow-over parameters at the beginning of the generatrix of the extraction chamber bottom are stationary, then a stationary flow is realized on the conical surface, which satisfies the system of equations:

$$
\begin{gathered}
\frac{d}{d x}[u h(l-x)]=0 ; \\
u \frac{d u}{d x}+g \sin \beta \frac{d h}{d x}=-\frac{\tau_{0}}{\rho h}+g \cos \beta ; \\
h(l-x)=q,
\end{gathered}
$$

where $u$ is pulp velocity along the generatrix of the extraction chamber bottom; $\rho$ is pulp density; $\tau_{0}$ is friction stress at the extraction chamber bottom, which can be found by the well-known Chezy formula:

$$
\tau_{0}=g \frac{\rho u^{2}}{C^{2}}
$$

where $C$ is Chezy coefficient. 
Chezy coefficientthe value of which is determined depending on the material and the relative roughness of the extraction chamber bottom using one of the known empirical formulas. For example, by the formula of N.N. Pavlovsky:

$$
C=\frac{x^{y}}{n}
$$

where $n$ is surface roughness factor; $y$ is empirical coefficient; $x$ is a hydraulic radius equal to the layer thickness $h$ for the annular flow-over over the conical surface.

The value of the roughness factor is determined from special tables and varies from 0.009 to 0.14 . The value of the hydraulic monitor performance according to the pulp $q$ is determined by the parameters of the process when hydraulic monitor outwashes the mineral deposit. The system of equations (3)-(5) can be solved by obtaining the following equations for $u$ and $h$ :

$$
\begin{gathered}
\frac{d u}{d x}=\frac{\left[g \cos \beta-\frac{g n^{2}}{q^{m}} u^{2+m}(l-x)^{m}-\frac{q g \sin \beta}{u(l-x)^{2}}\right] u^{2}(l-x)}{u^{3}(l-x)-q g \sin \beta} ; \\
\frac{d h}{d x}=\frac{g \cos \beta h^{3}(l-x)^{2}-\frac{g n^{2}}{h^{m-1}} q^{2}-\frac{q^{2} h}{l-x}}{g \sin \beta h^{3}(l-x)^{2}-q^{2}} .
\end{gathered}
$$

Differential equations (8) and (9) are equivalent, and any of them in combination with (10) determines the flow velocities and heights distribution along the generatrix of the extraction chamber bottom. Any of these equations can be solved numerically, if the initial data $u_{0}$ and $h_{0}$ with $x=0$ are specified. It should also be noted that the integral curves of equations (8) and (9) have been enough thoroughly studied in hydraulics.

Denominator is converted in the last equation to zero, thereby indicating that the flow reaches a critical depth at a given point, at which velocity reaches a critical value:

$$
\begin{gathered}
h_{k p}=\left[\frac{q^{2} \sin \beta}{g(R-x \sin \beta)^{2}}\right]^{1 / 3} ; \\
u_{k p}=\left(\frac{q g \sin ^{2} \beta}{R-x \sin \beta}\right)^{1 / 3} .
\end{gathered}
$$

The value of $h_{H}$, at which the numerator of equation (7) becomes zero, is called the local normal depth. The value of $h_{H}$ satisfies the equation:

$$
h_{H}^{2+m}-\frac{q^{2} \sin ^{3} \beta}{g \cos \beta(R-x \sin \beta)^{3}} h_{H}^{m}-\frac{n^{2} q^{2} \sin ^{2} \beta}{\cos \beta(R-x \sin \beta)^{2}}=0 .
$$

The peculiarity of equation (12) is that it can be solved without determining the velocity by solving the equations (8) and (9).

A jet of a hydraulic monitor with a flow rate of $Q_{W}$, when striking the face wall, reflects, loosens and outwashes a certain rock volume, and is characterized by a specific water flow rate per $1 \mathrm{~m}^{3}$ of rock. Thus, the volume of rock washed out per unit time and the flow rate of pulp inflowing the extraction chamber bottom will be equal to: 


$$
\begin{gathered}
Q_{p}=\frac{Q_{W}}{A}\left(1-m_{p}\right) ; \\
q_{0}=Q_{W} \frac{1-m_{p}+A}{A},
\end{gathered}
$$

where $Q_{p}$ is hydraulic monitor performance by the solid; $Q_{W}$ is water flow rate through the hydraulic monitor nozzles; $A$ is specific water flow rate for washout; $m_{p}$ is porosity of the rock which is washed out when it is in the state of pillars.

For a unit of time, the hydraulic monitor jet makes an angle equal to $\omega=2 \pi / T$, to which an arc of a circle corresponds on the face surface with a radius $R$ equal to $S_{T}=\omega R$. If at the point of the jet contacting with the face wall the jet diameter is equal to $d$, then the total perimeter length of the jet contacting with the rock is:

$$
L_{T}=S_{T}+d=\omega R+d .
$$

The value $L_{T}$ is the width of the flow flowing down the face wall with a total flow rate $q_{0}$ into the initial section of the inclined surface of the extraction chamber bottom.

Pulp flow-over process down the face wall until it hits the extraction chamber bottom will be close to vertical. Thus, the pulp velocity at the moment it hits the extraction chamber bottom, if to ignore the friction influencing the face wall, can be determined by the formula:

$$
u_{0}=k_{U} \sqrt{2 g \Delta Z},
$$

where $\Delta Z$ is distance between the jet axis contacting point with the face surface, as well as with the upper edge of the bottom surface of the extraction chamber; $k_{u}$ is empirical coefficient which takes into account the influence of friction and other physical and mechanical factors.

The layer thickness $h_{0}$ can be obtained from the flow-rate equation:

$$
h_{0}=\frac{Q_{W}}{(\omega R+d)} \frac{1-m_{p}+A}{A k_{U} \sqrt{2 g \Delta Z}} .
$$

The values of $u_{0}$ and $h_{0}$, calculated by formulas (16) and (17), serve as the initial values of $u$ and $h$ for the system of equations (13) - (17).

Based on the above research results with account of the mathematical dependences $(10)-(12)$ and (13) - (17), it has been determined that the parameters of the pulp flow-over along the extraction chamber bottom are obtained proceeding from the operating mode and hydraulic monitor characteristics. Transportation capacity of the flow depends on the hydraulic monitor flow rate, the chamber bottom inclination for the broken zeolite-smectite tuff-stones and is of linear nature; it is directly proportionally dependent on the specified parameters. To confirm the theoretical results obtained during the process of modelling, laboratory and field studies have been performed.

The zeolite-smectite tuff-stones of the Rafalivskyi basalt quarry have been studied by sieving of $1 \mathrm{~m}^{3}$ dump tuff-stone mass through vibratory screen before and after crushing. In this case, an unweakened tuff-stone was tested by several cycles of water application $[50,51]$.

It has been revealed that the largest pieces in unweakened dump mass of the tuff-stone have a size of $250-300 \mathrm{~mm}$ and their number is $2-3 \%$. When weakened, the maximum size of the pieces is $100-150 \mathrm{~mm}$, and their maximum number is not more than $5 \%$.

The study of the tuff-stone granular composition, mined by the method of downhole hydraulic mining, testifies that it has different characteristics depending on the weakening and significantly differs from that mined in a quarry [52]. 
Fig. 3, a shows the distribution of $Q_{K}(\mathrm{~mm})$ particle-size 1 and the weakened tuff-stone 2, and Fig. 3, $b$ shows the particle-size distribution of the tuff-stone, mined by downhole method. In the last case, the granular composition is experimentally determined in $1 \mathrm{~m}^{3}$ of the tuff-stone, washed out on the alluviation map.
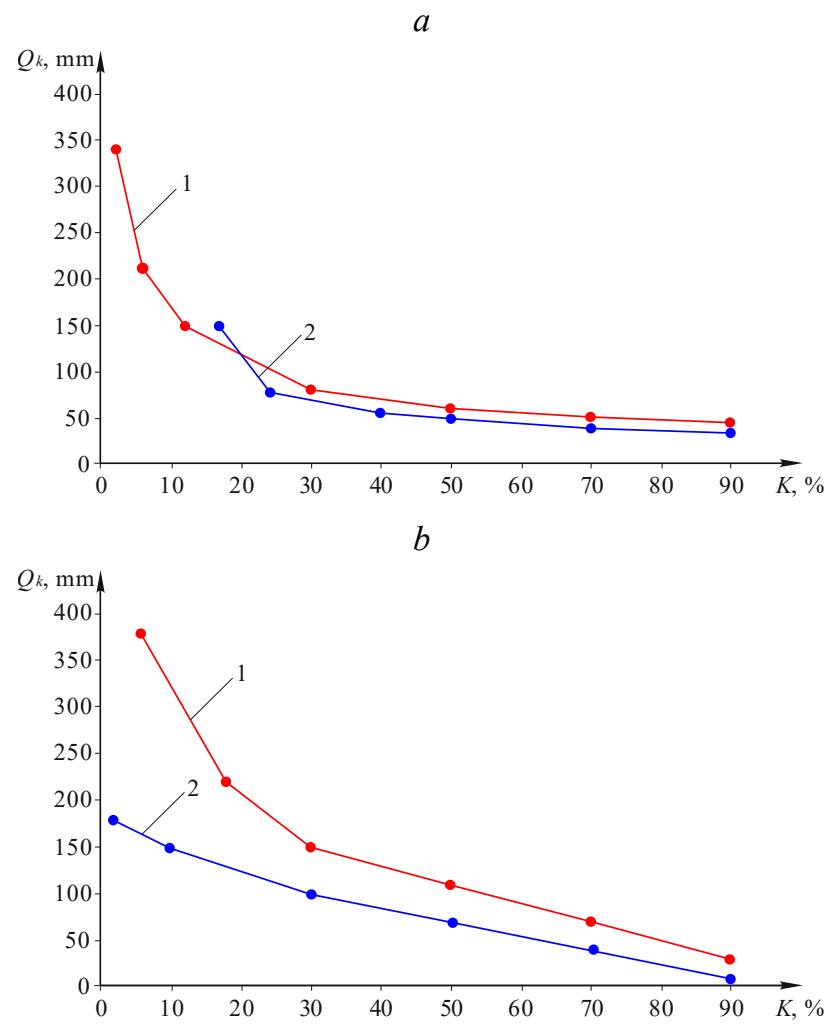

Fig. 3. Granulometric composition of the tuff-stone mined in a quarry (1) and by downhole method (2) before (a) and after (b) weakening (per $1 \mathrm{~m}^{3}$ of rock mass).

As a result of modelling representation for the distribution patterns research results of the granulometric tuff-stone composition dirung crushing, grinding and weakening (Fig. 4), and based on the experimental studies, the curves of the granular composition dependence of the tuff-stone mined in a quarry and by downhole method have been identified. For the unweakened and weakened tuff-stone, mined by both these methods, the dependence of the following form has been obtained:

$$
Q_{K}=a+\frac{b}{K} .
$$

The hyperbolic form of such a dependence is conditioned by the tuff-stones nature, since at small percentage values of the particle-size $K(\%)$, there is a sharp decrease in the particle-size of $Q$, and as $K$ increases, the curve is being flattened (Fig. 3, $a, b$ ). As a result, for an unweakened tuff-stone, a regression model of the following form has been obtained:

$$
Q_{K n}=61.02+\frac{304.98}{K},
$$

with the determination coefficient: $r^{2}=0.904$. 
For the weakened tuff-stone, model is as follows:

$$
Q_{K r}=-0.665+\frac{1901.66}{K} \text { at } r^{2}=0.981 .
$$

Based upon the determination coefficients, both models quite adequately describe the experimentally determined dependencies. It can be clearly observed, when comparing the experimental and calculated data shown in Fig. 4, $a$, $b$, where the calculated dependence is shown by a dashed line.

$a$
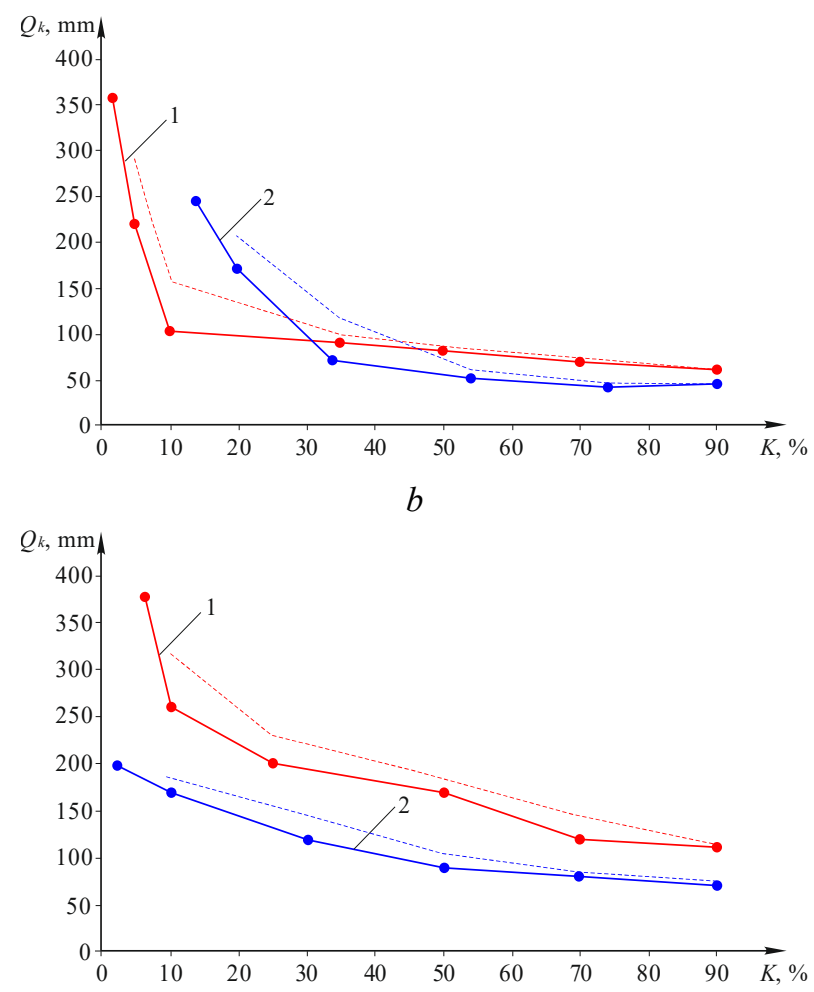

Fig. 4. Comparative evaluation of the experimental and calculated dependences of the granular composition of tuff-stone mined in a quarry (1) and by downhole method (2) before (a) and after (b) weakening.

The determination coefficients for all models are high, which indicates the adequacy of the obtained linear models to the experimental data.

Thus, the above research analysis evidences that the tuff-stone is a valuable raw material, which is of interest for the industry, since it contains valuable elements in the form of native copper, iron, and titanium. It is technologically possible and economically feasible to extract these components. Based on the geological research, the tuff-stone raw material reserves only in Volyn provide for a long-term production, and the products of processed tuff-stone can be widely used in Ukraine.

Currently, when quarrying, only basalt is used (mainly for the crushed stone production). Tuff-stone and lava-breccia, concomitant to it, are dumped rock mass, which is stored and is a technogenic deposit with a high content of native copper, iron, titanium and other valuable metals. 
Basalts are not extracted and processed in Ukraine to produce copper. The deposit is unique due to the native copper available on an industrial scale. Moreover, it is contained in three main components by the rock composition of a deposit - basalt, tuff-stone and lavabreccia. In addition, all three components have a high content of titanomagnetite, therefore, the possibility of the deposit complex processing is investigated. At the stage of preindustrial preparation, the main task is to obtain representative initial information about the deposit not only according to the geological and economic assessment of the deposit, but also in terms of the technological properties of the host rocks (crushing, classifying, recovery methods, percentage composition).

It is also important to analyse the peculiarities of the subsoil use development in the region, taking into account its infrastructure and the possibilities of processed products utilization, as well as the ecological situation [53, 54]. In this particular case, the implementation of integrated development in an existing quarry is much cheaper, and the time spent on the new technology introduction can also be reduced. To design an enterprise for integrated deposit development, to compile technical design specifications, it is necessary to obtain a significant scope of information and conduct an additional set of research.

Based on the research results, it is planned in an existing basalt quarry (in this case, Rafalivskyi quarry) to create a research and production site with its technological scheme for processing all three rock components of the deposit in order to determine availability, development of the technology, increase the industrial products efficiency and the possibility of implementing the waste-free technology. Since in world practice there is neither a similar deposit, nor technology for its processing, it is a question of creating a method for determining the availability of a deposit for an integrated, more complete mineral resources development. The method is based on determining the probability to exploit the deposit depending on the ore quality, percentage of useful components, mining conditions, volume of reserves and the rational use of serial mining equipment, as well as reconstruction or development of new, more advanced equipment.

Therefore, the issues of ore preparation and benefication of mined rock mass require serious development and industrial realization. For this purpose, it is proposed to build a research and production site for testing the technology of copper and iron recovery from basalt raw materials. The remaining silicate material can be used to produce basalt wool, which is currently widely used in construction and engineering (as an insulant). Most of the research has been performed at the laboratory level by the employees of the Institute of Geotechnical Mechanics named after N. Poljkov of National Academy of Sciences of Ukraine, (Dnipro) and the National University of Water Management Engineering in Rivne (Department of Mineral Deposits Development). At present, the issue remains urgent of developing the technologies and obtaining the finished products for economic and technological substantiation to construct a factory or plant for the integrated waste-free basalt raw materials processing.

\section{Conclusions}

The research has proved that the hydraulic monitor supply, the washout radius and the jet area at the moment of contact with the rock mostly influence on the pulp flow-over along the extraction chamber bottom. It has been determined that the kinetic energy of a hydraulic mixture movement along the extraction chamber bottom with the pulp flow falling down influences on the reduction of specific energy consumption during washed out tuff-stone transportation. At the same time, it is necessary to maintain turbulent motion on the periphery of the extraction chamber. In this case, the settling of tuff-stone particles is reduced in the flow, the maximum height of which should not exceed more than 2 times the size of the largest fractions in the broken rock. 
When the tuff-stone is mined in a quarry dumps, their water-cut predetermines weakening and reducing the lumpiness of the tuff-stone mass, without decreasing the lumpiness of other rocks in the dump (lava-breccia, quartz, basalt). This makes it possible to conduct selective tuff-stone extraction from the dump by means of fine vibratory screening.

Based on modelling and experimental studies performed, mathematical dependences have been determined that make possible to predict a change in the physical and mechanical tuff-stone properties over time under the influence of their moisture saturation, enabling calculation of the dynamic models of the tuff-stone hydraulic mixture flow-over along the extraction chamber bottom to the intaking hydraulic elevator headwall for further lifting to the day surface or alluviation map.

The distribution of granulometric composition when crushing and grinding of the tuffstone mined by downhole method and in a quarry in percentage terms satisfies the hyperbolic law and is modeled with sufficient accuracy by the regression model.

This work has been performed on the basis of the National University of Water Management Engineering (NUWME, Rivne) and with the participation of specialists from Rafalivskyi quarry (Rivne region, Volodymyrets district, Ivanchi). The authors express their gratitude to the management of Rafalivskyi quarry, represented by Director P.P. Bortnik for the opportunity to conduct research into deep-lying tuff-stones and the tuff-stones in the Rafalivskyi quarry dumps.

\section{References}

1. Li, L., Tan, Y., Huang, B., \& Deng, X. (2020). Pore property as an indicator of macrodeterioration in slightly weathered tuffs. Engineering Geology, (267), 105492. https://doi.org/10.1016/j.enggeo.2020.105492

2. Tarik, O.H., \& Bolatturk, A. (2006). The use of tuff stone cladding in buildings for energy conservation. Construction and Building Materials, 20(7), 435-440. https://doi.org/10.1016/j.conbuildmat.2005.01.064

3. Parisi, F., Balestrieri, C., \& Asprone, D. (2016). Nonlinear micromechanical model for tuff stone masonry: Experimental validation and performance limit states. Construction and Building Materials, (105), 165-175. https://doi.org/10.1016/j.conbuildmat.2015.12.078

4. Nadutyy, V.P., Malanchuk, Z.R., \& Prokopyuk, O.N. (2010). Obosnovanye neobkhodymosty kompleksnoy pererabotky tseolyt-smektytovykh tufov Volyny. Mater. Forum Hirnykiv, 50-55.

5. Soroka, M.P., Pol'ovyy, V.M. (2004). Vykorystannya vulkanichnykh tufiv Rivnenshchyny v hodivli sil's'kohospodars'kykh tvaryn. Visnyk ahrarnoyi nauky, (5), 42-44.

6. Dvorkin, L.Y. (2001). Bazal'tovi tufy - perspektyvna syrovyna dlya budivel'nykh keramichnykh vyrobiv. Visnyk RDTU, 3(10), 110-116.

7. Kacmaz, H. (2016). Major, trace and rare earth element (REE) characteristics of tuffs in the Yenice-Sarayc1k area (Demirci, Manisa), Western Anatolia, Turkey. Journal of Geochemical Exploration, (168), 169-176. https://doi.org/10.1016/j.gexplo.2016.06.014

8. Nadutyy, V.P., Prokopyuk, O.N., \& Levchenko, P.V. Rezul'taty yssledovanyy razuprochnenyya tufa v otvalakh bazal'tovykh kar'erov. Heotekhnichna mekhanika, (89), 120-126.

9. Stets', S.YE. (2006). Klasyfikatsiya rodovyshch tufiv za fizyko-khimichnymy vlastyvostyamy ta mineralohichnym skladom. Nauka. Tekhnika. Tekhnolohyia, 191-196.

10. Ammendola, P., Raganati, F., Chirone, R., \& Miccio, F. (2017). Preliminary assessment of Tuff as $\mathrm{CO}_{2}$ Sorbent. Energy Procedia, (114), 46-52. https://doi.org/10.1016/j.egypro.2017.03.1145

11. Mulyavko, V.I., Oleynik, T.A., Oleynik, M.O., Mikhno, S.V., \& Lyashenko, V.I. (2014). Innovation technologies and machinery for separation of feebly magnetic ores. Obogashchenie Rud, (2), 43-49. 
12. Gurin, A.A., Lyashenko, V.I., \& Taran, N.A. (2014). New technologies and means of tailings storage facilities dusting surface binding stabilization. Obogashchenie Rud, (5), 41-47.

13. Moshynskyi, V., Malanchuk, Z., Tsymbaliuk, V., Malanchuk, L., Zhomyruk, R., \& Vasylchuk, O. (2020). Research into the process of storage and recycling technogenic phosphogypsum placers. Mining of Mineral Deposits, 14(2), 95-102. https://doi.org/10.33271/mining14.02.095

14. Pivnyak, G., Bondarenko, V., Kovalevs'ka, I., \& Illiashov, M. (2012). Geomechanical Processes During Underground Mining, 238 p. Book. https://doi.org/10.1201/b13157

15. Cherniaiev, O.V. (2017). Systematyzatsiia nerudnykh rodovyshch skelnykh korysnykh kopalyn dlia vdoskonalennia tekhnolohii yikh vidpratsiuvannia. Naukovyi Visnyk NHU, (5), 11-17.

16. Arshamov, Y., Seitmuratova, E., \& Baratov, R. (2015). Perspectives of porphyry copper mineralizations in Zhongar-Balkhash fold system. International Multidisciplinary Scientific GeoConference Surveying Geology and Mining Ecology Management, 345-350.

17. Baibatsha, A., Arshamov, Y., Bekbotayeva, A., \& Baratov, R. (2017). Geology of the main industrial types of copper ore deposits in Kazakhstan. International Multidisciplinary Scientific GeoConference, Science and Technologies in Geology, Exploration and Mining, 17(11), 231-238. https://doi.org/10.5593/sgem2017/11/s01.029

18. Menshov, O., Sukhorada, A., Homenko, R., \& Kruglov, O. (2012). Ultradetailed Environmental Magnetic Investigations in Ukraine. Near Surface Geoscience 2012 - 18th European Meeting of Environmental and Engineering Geophysics, cp-306-00099. https://doi.org/10.3997/22144609.20143416

19. Menshov, O., Kuderavets, R., Chobotok, I., \& Tymoschuk, V. (2014). Magnetic Studies Associated with Hydrocarbon Fields in the Ukrainian Part of Carpathian Foredeep. Proceedings 76th EAGE Conference and Exhibition 2014, 61-65. https://doi.org/10.3997/2214-4609.20141252

20. Sejtmuratova, E.J., Arshamov, J.K., Baratov, R.T., \& Dautbekov, D.O. (2016). Geological and metallogenic features of volcano-plutonic belt. News of the National Academy of Sciences of the Republic of Kazakhstan, Series of Geology and Technical Sciences, 3(416), 60-86.

21. Seitmuratova, E., Arshamov, Y., Bekbotayeva, A., Baratov, R., \& Dautbekov, D. (2016). Priority metallogenic aspects of late paleozioc volcanic-plutonic belts. International Multidisciplinary Scientific GeoConference Surveying Geology and Mining Ecology Management, (1), 511-518. https://doi.org/10.5593/sgem2016/b11/s01.064

22. Sharapatov, A., Shayahmet, M., \& Arshamov, Y.K. (2016). About modern technology field geophysical research areas sulfide mineralization. News of the National Academy of Sciences of the Republic of Kazakhstan, Series of Geology and Technical Sciences, 1(415), 102-107.

23. Lustyuk, M. (2007). Fundamentals of mechanical and hydraulic mining. Scientific Bulletin of NSU. (3), 33-3.

24. Malanchuk, Z., Moshynskyi V., Malanchuk Y., Korniienko V., \& Koziar M. (2020). Results of Research into the Content of Rare Earth Materials in Man-Made Phosphogypsum Deposits. Key Engineering Materials, (844), S. 77-87. https://doi.org/10.4028/www.scientific.net/kem.844.77

25. Nadutyy, V.P., \& Grinyuk, T.Yu. (2007). Opredelenie zavisimostey soderzhaniya samorodnoy medi v bazal'takh ot massy i krupnosti prob. Visnik Natsional'nogo tekhnichnogo universitetu «Kharkivs'kiy politekhnichniy institut», (26), 87-93.

26. Kalinichenko, V., Pysmennyi, S., Shvaher, N., Kalinichenko, O. (2018). Selective underground mining of complex structured ore bodies of Kryvyi Rih Iron Ore Basin. E3S Web of Conferences, (60), 00041 https://doi.org/10.1051/e3sconf/20186000041.

27. Stupnik, M.I., Kalinichenko, V.O., Kalinichenko, O.V., Muzika, I.O., \& Fed'ko, M.B., Pis'menniy, S.V. (2015). The research of strain-stress state of magnetite quartzite deposit massif in the condition of mine "Gigant-Gliboka" of central iron ore enrichment works (CGOK). Metallurgical and Mining Industry, (7), 377-382.

28. Stupnik, M.I., Kalinichenko, O.V., Kalinichenko, V.O. (2012). Economic evaluation of risks of possible geomechanical violations of original ground in the fields of mines of Kryvyi Rih basin. Naukovyi Visnyk Natsionalnoho Hirnychoho Universytetu, (6), 126-130 
29. Masley, V.M., Mozgovoy, D.K., $\quad$ Bilousov, K.G., $\quad$ Horoshilov, V.S., $\quad$ Bushanska, O.S., $\quad \&$ Galich, N.G. (2016). Methods of the impact evaluation of amber mining by multispectral satellite images. Kosmicna Nauka i Tehnologia, 22(6), 26-36. https://doi.org/10.15407/knit2016.06.026

30. Keenan, J., Kemp, D., \& Owen, J. (2019). Corporate responsibility and the social risk of new mining technologies. Corporate Social Responsibility and Environmental Management, 26(2). https://doi.org/10.1002/csr.1717

31. Nadutyy, V.P., Erpert, A.M., \& Grinyuk, T.Yu. (2008). Opredelenie zakona raspredeleniya i kharaktera zavisimosti vykhoda izmel'chennoy porody i samorodnoy medi ot klassa krupnosti / Geotekhnicheskaya mekhanika, (75), 137-142..

32. Gumenik, S., Sokil, A., Semenenko, E., \& Shurygin, V. (2001). Problems of development of placer deposits. Sich, 224-235.

33. Abdiev, A.R. (2002). Evaluation of the stressed-strained state of rock massif for brown coal deposit in Kara-Keche. Gornyi Zhurnal, (10), 70-72.

34. Bondarenko, V., Kovalevs'ka, I., Svystun, R., \& Cherednichenko, Yu. (2013). Optimal parameters of wall bolts computation in the united bearing system of extraction workings frame-bolt support. Annual Scientific-Technical Colletion - Mining of Mineral Deposits, 5-9. https://doi.org/10.1201/b16354-2

35. Bondarenko, V., Kovalevs'ka, I., \& Ganushevych, K. (2014). Progressive technologies of coal, coalbed methane, and ores mining, 523 p. Book. https://doi.org/10.1201/b17547

36. Abdiev, A., Mambetova, R., Abdiev, A., \& Abdiev, Sh. (2020). Studying a correlation between characteristics of rock and their conditions. Mining of Mineral Deposits, 14(3), 87-100. https://doi.org/10.33271/mining14.03.087

37. Poturaev, V., Bulat, A., Voloshin, A., Ponomarenko, S., \& Voloshin, A. (2001). Mechanics of vibration-pneumatic ejector type machines. National Academy of Sciences of Ukraine. Institute of geotechnical mechanics. 176.

38. Bulat, A., \& Sokil, A. (2020). Non-stationary movement of a hydraulic mixture during condensation in technological equipment. Geotechnical mechanics, (22), 3-7.

39. Grinyuk, T.Yu. (2008). Obosnovanie neobkhodimosti kompleksnogo podkhoda k dobyche i pererabotke bazal'tov Volyni. Geotekhnicheskaya mekhanika, (74), 67-71.

40. Malanchuk, Y., Korniienko, V., Moshynskyi, V., Soroka, V., Khrystyuk, A., \& Malanchuk, Z. (2019). Regularities of hydromechanical amber extraction from sandy deposits. Mining of Mineral Deposits, 13(1), S. 49-57. https://10.33271/mining13.01.049

41. Baranov, V.A., Grinyuk, T.Yu., \& Zhorushkina, O.A. (2007). Rezul'taty issledovaniy formirovaniya otdel'nostey pri razlichnykh usloviyakh razrusheniya. Geotekhnichna mekhanika:, 69, 57-64.

42. Malanchuk, Z.R., Moshynskyi, V.S., Korniienko, V.Y., Malanchuk, Y.Z., \& Lozynskyi, V.H. (2019). Obgruntuvannia parametriv rozmyvu y peretikannia pulpy tseolit-smektytovoho tufu u vydobuvnii kameri. Scientific Bulletin of the National Mining University, (6), 11-18.

43. Moshynsky, V. (2001). Modern water conditions in the northwest part of Ukraine: An analysis. Water Engineering and Management, 148(4), 22-26.

44. Malanchuk, Z., Korniyenko, V., Malanchuk, Y., \& Khrystyuk, A. (2016). Results of experimental studies of amber extraction by hydromechanical method in Ukraine. Eastern-European Journal of Enterprise Technologies, 3(10(81)), 24. https://doi.org/10.15587/1729-4061.2016.72404

45. Korniyenko, V.Ya., Malanchuk, E.Z., Soroka, V.S., \& Khrystyuk, A.O. (2018). Analysis of the existent technologies of amber mining. Resources and resource-saving technologies in mineral mining and processing, 209-232.

46. Inflated, V., Lapshin, E., \& Prokopishin, L. (2003). Experimental studies of the influence of vibration exciter parameters on the segregation process. Geotechnical mechanics, (42), 136-142.

47. Inflated, V., \& Lapshin, E. (2005). Probabilistic processes of vibrational classification of mineral raw materials. Naukova Dumka, (179), 145-162. 
48. Naduty, V., Malanchuk, Z., Malanchuk, E., \& Korniyenko, V. (2015). Modeling of vibro screening at fine classification of metallic basalt. New Developments in Mining Engineering, 441443. https://doi.org/10.1201/b19901-77

49. Malanchuk, Z., Korniienko, V., Malanchuk, Ye., Soroka, V., \& Vasylchuk, O. (2018). Modeling the formation of high metal concentration zones in man-made deposits. Mining of Mineral Deposits, 12(2), 76-84. https://doi.org/10.15407/mining12.02.076

50. Naduty, V., Malanchuk, Z., Malanchuk, Y., \& Korniyenko, V. (2016). Research results proving the dependence of the copper concentrate amount recovered from basalt raw material on the electric separator field intensity. Eastern-European Journal of Enterprise Technologies, $5(5$ (83)), 19-24. https://doi.org/10.15587/1729-4061.2016.79524

51. Nadutyy, V.P., \& Grinyuk, T.Yu. (2007). Metodika opredeleniya udel'noy treshchinovatosti i kharaktera blochnosti porody ustupa Rafalovskogo bazal'tovogo kar'year. Institut geotekhnicheskoy mekhaniki im. N.S. Polyakova NAN Ukrainy. Dnepropetrovsk, 1-6.

52. Dryzhenko, A., Moldabayev, S., Shustov, A., Adamchuk, A., \& Sarybayev, N. (2017). Open pit mining technology of steeply dipping mineral occurences by steeply inclined sublayers. International Multidisciplinary Scientific GeoConference Surveying Geology and Mining Ecology Management, SGEM, 17(13), 599-606. https://doi.org/10.5593/sgem2017/13/s03.076

53. Gorova, A., Pavlychenko, A., \& Borysovs'Ka, O. (2013). The study of ecological state of waste disposal areas of energy and mining companies. Mining of Mineral Deposits, 169-172. https://doi.org/10.1201/b16354-29

54. Buzylo, V., Pavlychenko, A., Savelieva, T., \& Borysovska, O. (2018). Ecological aspects of managing the stressed-deformed state of the mountain massif during the development of multiple coal layers. E3S Web of Conferences, (60), 00013. https://doi.org/10.1051/e3sconf/20186000013 